\section{Analysis of Turbulent Flow Field Induced by Rotating Electromagnetic. Field in Round Billets}

By Sumio KовAYASHi et al.

回転電磁界によつて丸ビレット中に誘起された流動場 を乱流 $k W$ モデルを用いて 解析した. 解析結果に基つ き，筧拌速度および壁面剪断力を表す簡単な方程式を導 いた。 実験を行い, 解析結果の妥当性を確認した.

Oxidation Behavior of Austenitic Heat-resisting Steels in a High Temperature and High Pressure Steam Environment

By Yasuo Otoguro et al.

芙ボイラーとほぼ同じ条件下で作動する水蒸気酸化試 験装置を用いて，水蒸気酸化におよぼす温度および圧力 (特に臨界圧力以上) の影響を SUS347HTB, 17〜14CuMo オーステナイト耐熱鋼および高性能石炭火力発電プ ラント用に新しく開発された $20 \mathrm{Cr}-25 \mathrm{Ni}, 22 \mathrm{Cr}-35 \mathrm{Ni}$ 鋼について調べた. 酸化減量は蒸気圧力および温度の上 昇とともに増大した．酎酸化性は $\mathrm{Cr}$ 量, $\mathrm{Ni}$ 量の増加 によつて改良された. 内層スケール中の $\mathrm{Cr}$ 濃度は鋼の Cr とともに増大した.これは耐水蒸気酸化性向上の原 因となつた．スケールと金属界面での $\mathrm{Ni}$ 富化層の存在 は水蒸気酸化抵抗の改良に役立つていた。 この層の $\mathrm{Ni}$ 濃度は鋼の Ni 量が多いほど高くなつた. スケール断面 の形態を調べた結果，高温高圧の水蒸気中で酸化された SUS347HTB と 17〜14CuMo 鋼の外層スケール中にか なり多量のボイドと空隙が生じることが分かつた.

\section{Analysis of Zinc-alloy Electroplated Steel Sheet by Glow Discharge Emission Spectrometry}

By Yoichi IsHibashi et al.

グロー放電発光分光分析をもちいた，覀鉛電気めつき 鋼板のめつき層化学成分の深さ分布に関する定量方法の
検討を行つた. 積分発光強度による化学成分の深さ分布 に関する最適な方法を確立した．合金電気めつき鋼板の 場合，スパッタリング効率と原子の発光効率は合金組成 に依存する．検量方法はプロファイル強度の補正によつ て改善された．定量の正確度は付着量 $5 \sim 50 \mathrm{~g} / \mathrm{m}^{2}$ の $\mathrm{Zn}-\mathrm{Fe}$ 合金電気めつき層に対して, $\mathrm{Zn}$ が $0.78 \mathrm{~g} / \mathrm{m}^{2}$, $\mathrm{Fe}$ が $0.45 \mathrm{~g} / \mathrm{m}^{2}$ であり, 付着量 $3 \sim 20 \mathrm{~g} / \mathrm{m}^{2}$ の $\mathrm{Zn}$ $\mathrm{Ni}$ 合金電気めつき層に対して, $\mathrm{Zn}$ かi $0.23 \mathrm{~g} / \mathrm{m}^{2}, \mathrm{Ni}$ が $0.03 \mathrm{~g} / \mathrm{m}^{2}$ であつた.

この方法は工場の操業管理のための分析にもちいられ ている.

\section{Research Note}

The Effect of Triangularly Waved Metal Fiber on Fracture Behavior of Brittle Matrix Composites

By Makoto SAITo et al.

き裂の進展を抑制するといら観点から，セラミック基 複合材の構造材料としての信頼性を改善する試みを三 角波状の繊維を強化材として用いて行つた. 試験材は $\mathrm{Al}_{2} \mathrm{O}_{3}$ /タングステン複合材である.

三点曲げ試験で強度の低下を伴わずにある程度の永久 変形を示し, 荷重一たわみ曲線は明らかな階段状の変化 を示した.これらの現象は㵶維の破断しない小さな変形 領域で観察された. 繰返し負荷に対して三角波状緎維強 化複合材は直線㵶維強化複合材に比べ, たわみの進行や 強度の低下に対する優れた抵抗を示した. シャルピー衝 撃試験では, 直線緘維強化複合材は試験片全体に剖離が 発生したが, 三角波状繊維強化複合材では剥離は全く観 察されなかつた。

き裂進展経路の観察結果から三角波状織維がき裂を分 岐および屈曲させることにより，き裂経路に著しい影響 を及ぼすことが明らかになつた。 き裂進展抑制のメカ二 ズムについて，き裂の分岐や屈曲による応力拡大係数の 低下するといら観点から検討した。

会員には「鉄と鋼」あるいは「Trans. ISIJ」のいずれかを毎号無料で配付いたします.「鉄と鋼」と「Trans. ISIJ」 の両誌希望の会員には, 特別料金 5,000 円の追加で両誌が配付されます.

\section{第 19 回疲労シンポジゥム講演募集}

1. 主 催 日本材料学会

2. 協 賛 日本鉄鋼協会, 他

3. 期 日 昭和 63 年 11 月 8 日 (火) 10 日 (木)

4. 全 場 立命館大学 末川記念会館 (京都市北区等 持院北町) Tel. (075) 463-0604

5. 講演分野 1. 疲労き裂の発生と進展, 2. 実働条件下 の疲労, 3. 疲労に及ぼす環境効果 (温度 環境を含む)，4. 時効の影響および疲労 機構, 5.低サイクル疲労之熱疲労, 6.新 材料の疲労特性, 7.疲労の信頼性工学的 検討, 8. 実物部材の疲労之耐疲労設計, 9.疲労に拉けるコンピュータ利用技術, 10 . 余寿命評価・延命技術

6. 講演申込締切 昭和 63 年 7 月 9 日（土）
7. 前刷原稿締切 昭和 63 年 9 月 10 日（土）

8. 申込先 日本材料学会第19回疲労シンポジウム俰 （广606 京都市左京区吉田泉殿町 1 番地の 101 Tel. (075) 761-5321)

\section{訂 正}

技術報告「高温，高品贸スラブ製造のための連続鋳 造二次冷却技術」（鉄と鋼， 74 (1988) 7, p. 1282) p. 1287，（6）式を次のとおり訂正させていただき ます。
(誤)
$\varepsilon_{B}=17.5 W_{j} l / F x^{2}$
(正) $\varepsilon_{B}=17.5 W_{j} l^{2} / F x^{2}$ 